Supporting Information

\title{
Carbon@Tellurium Nanostructures Anchored to a Si Nanowire Scaffold with an Unprecedented Liquid Junction Solar Cell Performance
}

\author{
Ankita Kolay, ${ }^{a}$ Debanjan Maity, ${ }^{a}$ Partha Ghosal, ${ }^{b}$ Melepurath Deepa ${ }^{a, *}$
}

aDepartment of Chemistry, Indian Institute of Technology Hyderabad, Kandi, Sangareddy, Telangana 502285, India

${ }^{\mathrm{b}}$ Defence Metallurgical Research Laboratory, Defence Research \& Development Organisation (DRDO), Hyderabad, Telangana 500058, India

*Email: mdeepa@iith.ac.in 


\section{Supporting Information}

\section{Chemicals}

n-type silicon (100) wafers $(\mathrm{CZ}$, resistivity 5-10 $\Omega \mathrm{cm})$ were acquired from Siegert wafer. Tellurium Oxide $\left(\mathrm{TeO}_{2}\right)$, silver nitrate $\left(\mathrm{AgNO}_{3}\right)$, hydrazine hydrate $\left(\mathrm{N}_{2} \mathrm{H}_{6} \mathrm{O}\right)$ were purchased from Aldrich. Dimethyl formamide $\left(\mathrm{C}_{3} \mathrm{H}_{7} \mathrm{NO}\right)$, tetrahydofuran (THF), sulfuric acid $\left(\mathrm{H}_{2} \mathrm{SO}_{4}, 98 \%\right)$, nitric acid $\left(\mathrm{HNO}_{3}, 69 \%\right)$, hydrogen peroxide $\left(\mathrm{H}_{2} \mathrm{O}_{2}, 30 \%\right)$, hydrofluoric acid ( $\left.\mathrm{HF}, 40 \%\right)$, hydrobromic acid $(\mathrm{HBr}, 47 \%)$, ethanol and acetone were bought from Merck. Bromine $\left(\mathrm{Br}_{2}\right)$ and D-glucose $\left(\mathrm{C}_{16} \mathrm{H}_{12} \mathrm{O}_{6}\right)$ were bought from SDFCL, C-fabric was procured from Alibaba Pvt. Ltd and ultra-pure water with a resistivity of $\sim 18.2 \mathrm{M} \Omega \mathrm{cm}$ was obtained through a Millipore Direct-Q3 UV system.

\section{Characterization techniques}

XRD patterns were recorded on a PANalytical, X'PertPRO instrument with a $\mathrm{Cu} \mathrm{K} \alpha(\lambda=1.5406$ $\AA$ ) radiation as the X-ray source. Raman spectra were recorded on a Bruker Senterra dispersive Raman microscope spectrometer, with a $532 \mathrm{~nm}$ laser excitation. Surface morphology analysis was performed using field emission scanning electron microscopy (FESEM; Carl Zeiss Supra 40). Transmission electron microscopy (TEM) images were obtained for trigonal selenium on a JEOL 2100 microscope operating at an accelerating voltage of $200 \mathrm{kV}$. The optical absorption spectra were measured in the diffuse reflectance mode and converted to absorbance using the Kubelka-Munk function on a UV-VIS-NIR spectrophotometer equipped with an integrating sphere (Shimadzu UV-3600). A Horiba Fluoromax-4 spectrometer was used for recording fluorescence spectra. The Current versus potential $(\mathrm{I}-\mathrm{V})$ data of solar cells were measured using a LOT-Oriel solar simulator coupled with a Metrohm Autolab PSTAT302N. The light source was a $150 \mathrm{~W}$ Xenon arc lamp, which delivered a collimated output beam of $25 \mathrm{~mm}$ diameter through Air Mass (AM) 1.5 filter, providing a light intensity of $100 \mathrm{~mW} \mathrm{~cm} \mathrm{~cm}^{-2}(1 \mathrm{sun})$. The spatial uniformity of irradiance was confirmed by calibrating with a $2 \mathrm{~cm} \times 2 \mathrm{~cm}$ Si reference cell and reaffirmed with a Newport power meter. IPCE versus wavelength was measured on a Newport machine with a tunable Xe lamp (300 W) as the light source. Electrochemical impedance spectra (EIS) for the cells were recorded on an Autolab PGSTAT 302N equipped with a frequency response analyzer (FRA) and a NOVA 1.11 software, under an AC amplitude of $20 \mathrm{mV}$ over the frequency range of $1 \mathrm{MHz}$ to $0.1 \mathrm{~Hz}$. Photovoltage decay versus time and photocurrent versus time data were recorded in dark by chronopotentiometric and chronoamperometric measurements respectively using an 
Autolab PGSTAT 302N coupled with a tungsten-halogen lamp as the white light source. The MottSchottky plots of TeNRs and C@TeNRs were derived from dark EIS measurement with Pt and $\mathrm{Ag} / \mathrm{AgCl} / \mathrm{KCl}$ as counter and reference electrode respectively using $0.1 \mathrm{M} \mathrm{HBr}$ as the electrolyte. Cyclic voltammograms (CV) of TeNRs and C@TeNRs deposited over FTO glass substrates serving as working electrodes were recorded in a three electrode cell, with a Pt rod as the counter electrode and $\mathrm{Ag} / \mathrm{AgCl} / \mathrm{KCl}$ as the reference electrode in an aqueous $0.1 \mathrm{M} \mathrm{KCl}$ electrolyte solution at a scan rate of $20 \mathrm{mV} \mathrm{s}^{-1}$. For the $\mathrm{CV}$ measurement of $\mathrm{Pt}$ and C-fabric (as working electrodes) the electrolyte was replaced with an aqueous $8.6 \mathrm{M} \mathrm{HBr} / 0.05 \mathrm{M} \mathrm{Br}_{2}$ solution keeping the other two electrodes unchanged. Conductance $(\mathrm{G})$ was measured by linear sweep voltammetry (LSV) using an FTO glass substrate and a stainless steel (SS) plate as the two electrodes for sandwiching the powder with a $2 \mathrm{~mm}$ wide para-film spacer in between. 

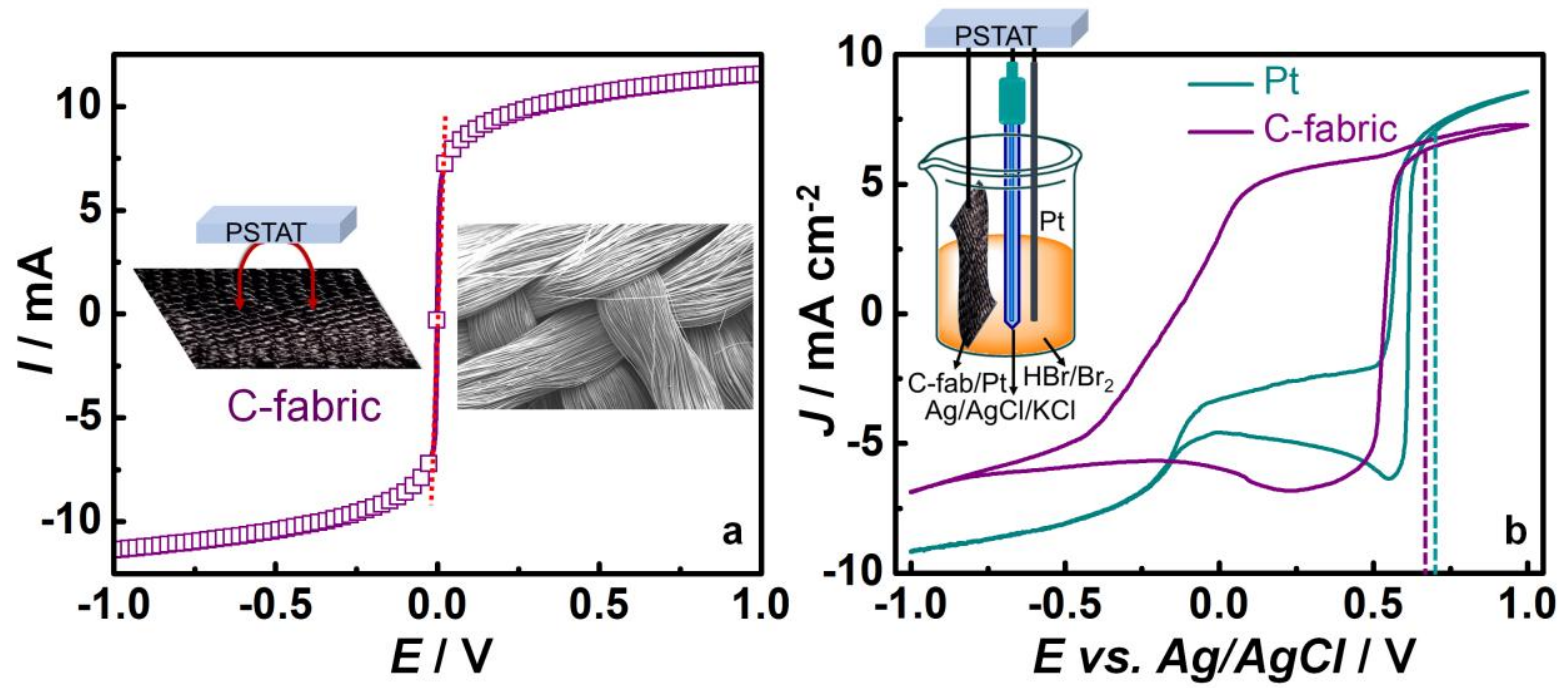

Figure S1 (a) I-V characteristics of C-fabric recorded in the configuration shown as an inset along with the SEM image (scale bar $=200 \mu \mathrm{m}$ ); the dotted line is the linear fit. (b) Cyclic voltammograms of the two CEs: Pt and C-fabric (measurement setup shown as an inset).

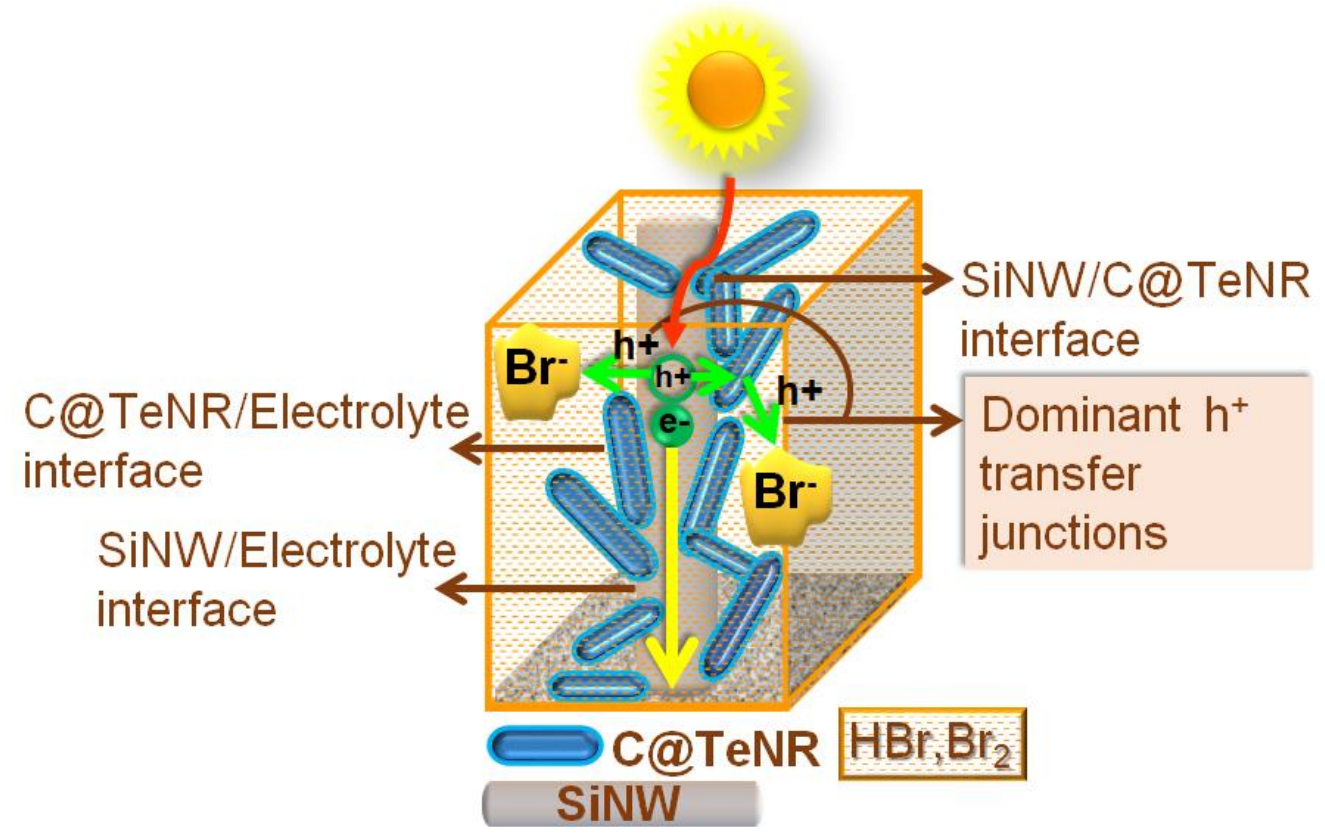

Scheme S1 Interfaces in the C@TeNRs@SiNW-electrolyte configuration. 
The HOMO (VB), LUMO (CB) and band gap values of SiNWs and C@TeNRs used in cell fabrication were acquired from cyclic voltammograms and absorbance spectra using the equations provided below.

$$
\begin{aligned}
& \mathrm{E}_{\mathrm{red}}=-4.5 \mathrm{eV}(\equiv 0 \mathrm{~V} \text { versus } \mathrm{NHE})-(\text { Red. Peak }(\mathrm{V}) \text { vs. } \mathrm{Ag} / \mathrm{AgCl} / \mathrm{KCl}+0.197 \mathrm{~V}) \\
& \mathrm{E}_{\mathrm{ox}}=-4.5 \mathrm{eV}(\equiv 0 \mathrm{~V} \text { versus } \mathrm{NHE})-(\mathrm{Ox} . \text { Peak }(\mathrm{V}) \text { vs. } \mathrm{Ag} / \mathrm{AgCl} / \mathrm{KCl}+0.197 \mathrm{~V})
\end{aligned}
$$

Table S1 Energy level positions of the photoanode components.

\begin{tabular}{|l|l|l|l|l|l|}
\hline Material & $\begin{array}{l}\text { Reduction } \\
\text { peak / V vs. } \\
\mathrm{Ag} / \mathrm{AgCl}\end{array}$ & $\begin{array}{l}\text { Oxidation } \\
\text { peak / V vs. } \\
\mathrm{Ag} / \mathrm{AgCl}\end{array}$ & $\begin{array}{l}\text { E } \\
\text { NHEd } \text { (versus } \\
\text { LUMO }\end{array}$ & $\begin{array}{l}\text { Band Gap / } \\
\mathrm{eV}\end{array}$ & $\begin{array}{l}\mathrm{E}_{\text {ox }} \text { (versus } \\
\text { NHE) / eV } \equiv \\
\text { HOMO }\end{array}$ \\
\hline \multirow{2}{*}{ C@TeNRs } & $-0.506(\mathrm{Te})$ & --- & $-4.191(\mathrm{Te})$ & $0.35(\mathrm{Te})$ & $-4.541(\mathrm{Te})$ \\
\cline { 2 - 6 } & $-0.776(\mathrm{C})$ & --- & $-3.921(\mathrm{C})$ & --- & --- \\
\hline SiNWs & --- & 0.507 & -4.114 & 1.09 & -5.204 \\
\hline
\end{tabular}

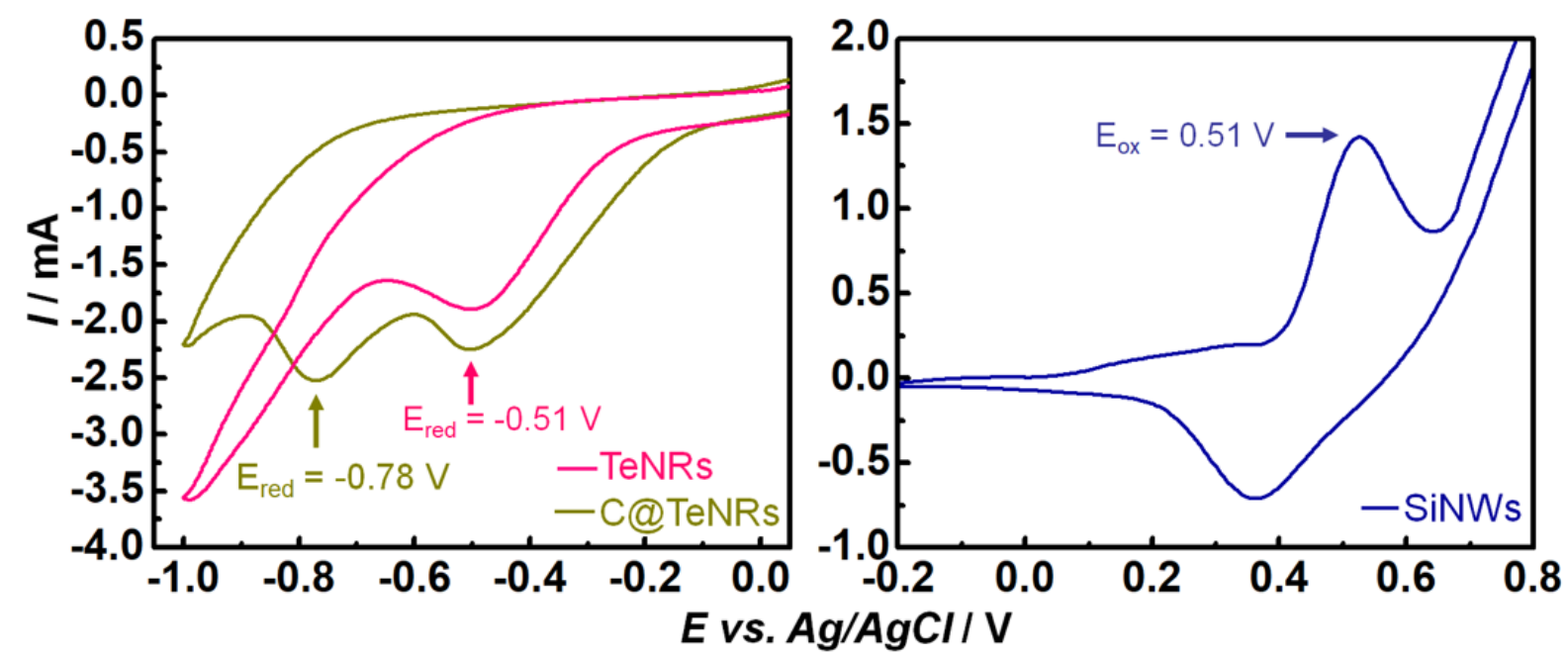

Figure S2 Cyclic voltammograms of TeNRs/FTO glass, C@TeNRs/FTO glass and SiNWs etched wafer. 
Table S2 LJSC parameters, their average and standard deviation of the 5-devices for each of the different photoanodes with $\mathrm{C}$-fabric counter electrode in $8.6 \mathrm{M} \mathrm{HBr} / 0.05 \mathrm{M} \mathrm{Br}_{2}$ aqueous electrolyte, exposed cell area: $\sim 0.5 \mathrm{~cm}^{2}$, under 1 sun illumination (AM $1.5,100 \mathrm{~mW} \mathrm{~cm}{ }^{-2}$ ).

\begin{tabular}{|c|c|c|c|c|}
\hline Cells & $\mathrm{V}_{\mathrm{OC}}(\mathrm{mV})$ & $\begin{array}{c}\mathrm{J}_{\mathrm{SC}} \\
\left(\mathrm{mA} \mathrm{cm}{ }^{-2}\right)\end{array}$ & $\mathrm{FF}$ & $\begin{array}{c}\text { Efficiency } \\
\qquad(\eta \%)\end{array}$ \\
\hline \multicolumn{5}{|c|}{ SiNWs - C-fabric } \\
\hline Cell 1 & 740 & 14.09 & 0.46 & 4.80 \\
\hline Cell 2 & 737 & 14.35 & 0.45 & 4.76 \\
\hline Cell 3 & 740 & 13.28 & 0.47 & 4.62 \\
\hline Cell 4 & 735 & 13.67 & 0.45 & 4.55 \\
\hline Cell 5 & 732 & 13.86 & 0.44 & 4.49 \\
\hline Average & $737 \pm 3.4$ & $13.85 \pm 0.41$ & $0.46 \pm 0.010$ & $4.64 \pm 0.13$ \\
\hline \multicolumn{5}{|c|}{ Te@SiNWs - C-fabric } \\
\hline Cell 1 & 791 & 18.23 & 0.51 & 7.31 \\
\hline Cell 2 & 789 & 18.12 & 0.51 & 7.29 \\
\hline Cell 3 & 793 & 17.36 & 0.53 & 7.24 \\
\hline Cell 4 & 787 & 17.54 & 0.52 & 7.15 \\
\hline Cell 5 & 787 & 18.00 & 0.50 & 7.08 \\
\hline Average & $789 \pm 2.6$ & $17.85 \pm 0.38$ & $0.51 \pm 0.011$ & $7.21 \pm 0.10$ \\
\hline \multicolumn{5}{|c|}{ C@TeNRs@SiNWs-C-fabric } \\
\hline Cell 1 & 893 & 23.27 & 0.56 & 11.59 \\
\hline Cell 2 & 895 & 22.64 & 0.57 & 11.55 \\
\hline Cell 3 & 892 & 23.28 & 0.55 & 11.52 \\
\hline Cell 4 & 889 & 23.05 & 0.56 & 11.48 \\
\hline Cell 5 & 885 & 23.96 & 0.54 & 11.45 \\
\hline Average & $891 \pm 3.9$ & $23.24 \pm 0.48$ & $0.56 \pm 0.011$ & $11.52 \pm 0.06$ \\
\hline
\end{tabular}



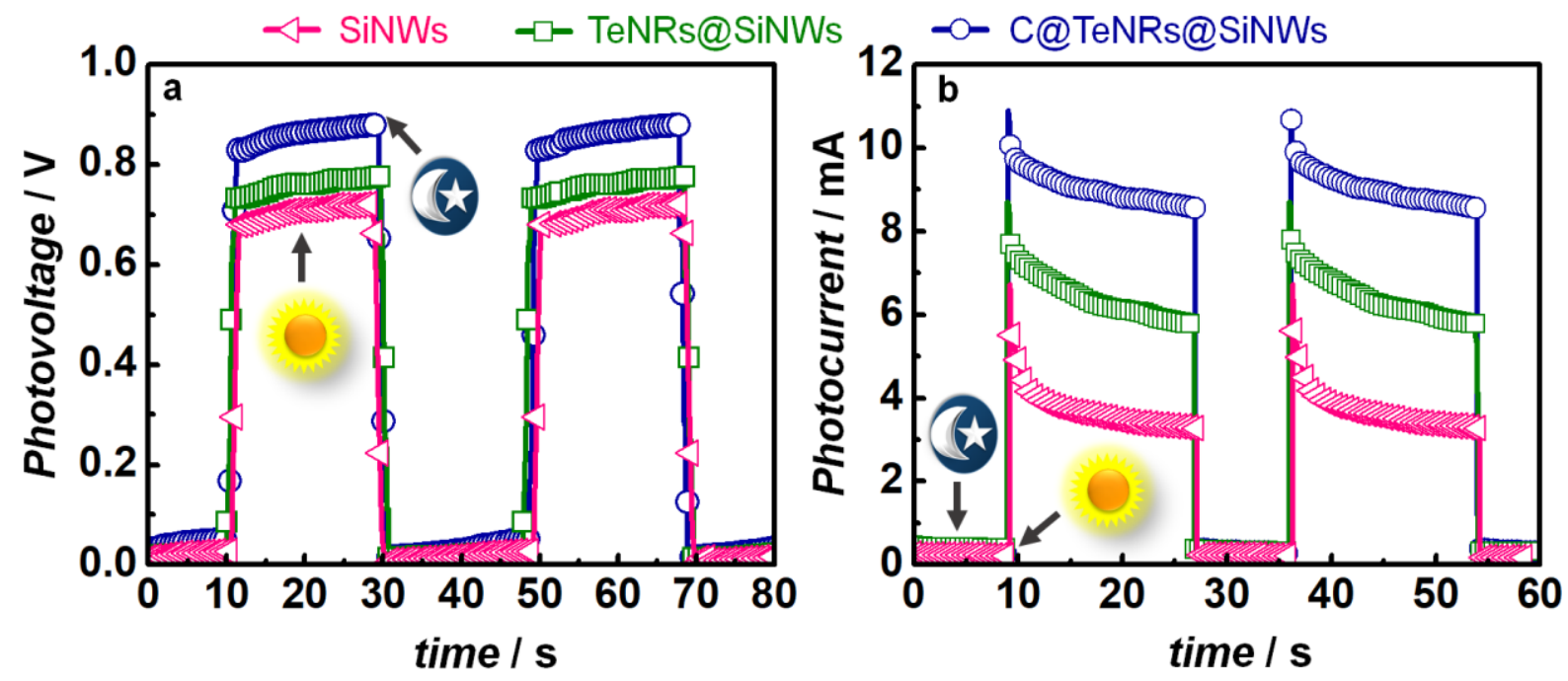

Figure S3 (a) Photovoltage versus time and (b) photocurrent versus time transients of LJSCs with different photoanodes in dark and under white light irradiance.

In the photocurrent versus time measurements (Figure S3b), the light power used is $100 \mathrm{~mW} \mathrm{~cm}^{-}$ ${ }^{2}$, and the cell area illuminated is $\sim 0.5 \mathrm{~cm}^{-2}$, in each case. The highest photocurrent delivered by the Si NW-based cell is $13.5 \mathrm{~mA} \mathrm{~cm}{ }^{-2}$ which rapidly decays and stabilizes to $7 \mathrm{~mA} \mathrm{~cm}{ }^{-2}$ photocurrent within few seconds of the initial irradiation time. The TeNRs@SiNWs and C@TeNRs@SiNWs cells show maximum responses of $21.7 \mathrm{~mA} \mathrm{~cm}^{-2}$ and $17.4 \mathrm{~mA} \mathrm{~cm}{ }^{-2}$ which also drop to stable values of $17.8 \mathrm{~mA} \mathrm{~cm}^{-2}$ and $12.3 \mathrm{~mA} \mathrm{~cm}^{-2}$ respectively. The decay observed for C@TeNRs@SiNWs is relatively slower than that of the others. The initial decay in the photocurrent is due to the oxidation of the silicon surface induced by the redox electrolyte when in contact thereby increasing the series resistance of the device. The adhering of the TeNRs over the SiNWs surface increases its surface roughness which in turn minimizes the series resistance by considerably suppressing the oxidizing effect of the electrolyte to stabilize the photocurrent. Further by coating the TeNRs with the chemically stable carbon film passivates both the Te core as well as the SiNW surfaces at the TeNR/SiNW junction and protects them against photocorrosion. These data are in good correlation with the J-V characteristics discussed in the manuscript. 
Table S3 EIS parameters obtained from the fitted Nyquist plots of LJ PEC solar cells with different listed photoanodes under dark and illumination.

\begin{tabular}{|l|l|l|l|l|l|l|l|}
\hline Photoanode & $\mathrm{R}_{1}(\Omega)$ & $\mathrm{R}_{2}(\Omega)$ & $\begin{array}{l}\mathrm{Y}_{\mathrm{o} 1} \\
\left(\mu \Omega^{-1}\right)\end{array}$ & $\mathrm{N}_{1}$ & $\mathrm{R}_{3}(\Omega)$ & $\begin{array}{l}\mathrm{Y}_{\mathrm{o} 2} \\
\left(\mu \Omega^{-1}\right)\end{array}$ & $\mathrm{N}_{2}$ \\
\hline SiNWs & 65.5 & 160 & 11.2 & 0.676 & 217 & 279 & 0.674 \\
\hline TeNRs@Si NWs & 63.6 & 159 & 11.0 & 0.839 & 278 & 238 & 0.764 \\
\hline C@TeNRs@SiNWs & 62.5 & 135 & 13.8 & 0.707 & 338 & 628 & 0.610 \\
\hline SiNWs (light) & 59.7 & 70.7 & 5.41 & 0.593 & 99.3 & 232 & 0.783 \\
\hline TeNRs@SiNWs (light) & 58.4 & 67.3 & 25.4 & 0.646 & 105 & 325 & 0.768 \\
\hline C@TeNRs@SiNWs (light) & 57.8 & 60.3 & 2.31 & 0.712 & 139 & 548 & 0.586 \\
\hline
\end{tabular}

Table S4 Effect of prolonged continuous 1 sun illumination on a cell with C@TeNRs@ $@ \mathrm{SiNWs}_{\mathrm{B}} \mathrm{Br}^{-}$ , $\mathrm{Br}_{2} / \mathrm{C}$-fabric configuration (active area $\sim 0.5 \mathrm{~cm}^{2}$ ).

\begin{tabular}{|l|l|l|l|l|}
\hline Illumination & Voc $(\mathrm{mV})$ & Jsc $\left(\mathrm{mA} \mathrm{cm}^{-2}\right)$ & FF & PCE (\%) \\
\hline $0 \mathrm{~h}$ & 893 & 23.10 & 0.56 & 11.53 \\
\hline $1 \mathrm{~h}$ & 878 & 22.39 & 0.54 & 10.60 \\
\hline $2 \mathrm{~h}$ & 859 & 20.06 & 0.51 & 8.79 \\
\hline $3 \mathrm{~h}$ & 827 & 18.91 & 0.50 & 7.84 \\
\hline $4 \mathrm{~h}$ & 795 & 15.75 & 0.49 & 6.15 \\
\hline $5 \mathrm{~h}$ & 782 & 14.68 & 0.47 & 5.42 \\
\hline $6 \mathrm{~h}$ & 770 & 13.32 & 0.46 & 4.68 \\
\hline
\end{tabular}



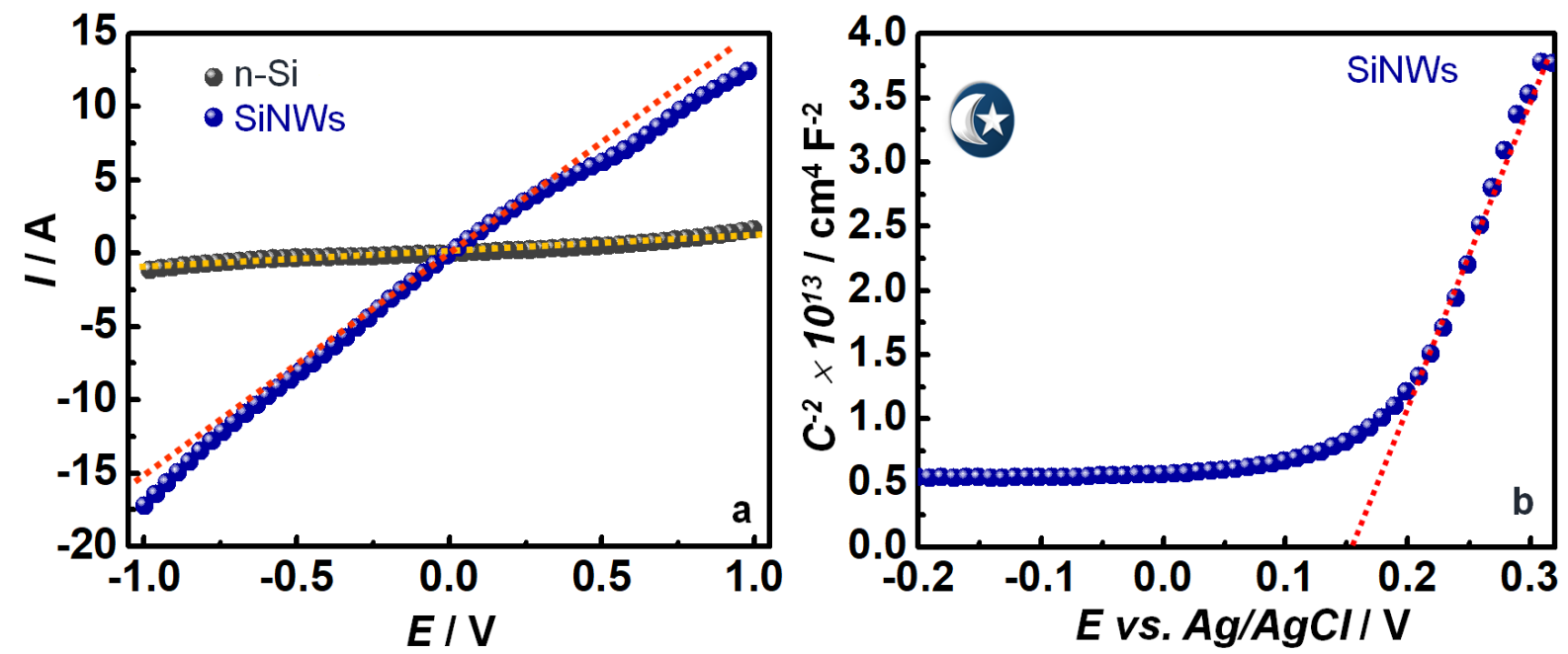

Figure S4 (a) I-V characteristics of planar Si and etched SiNWs. Dotted lines represent the linear fits. (b) Mott-Schottky plot of SiNWs etched wafer in dark.

The positive slope of the $1 / \mathrm{C}^{2}$ versus $\mathrm{E}$ profile of SiNWs at $10^{5} \mathrm{~Hz}$ in the above Figure S4b confirms its n-type nature, typical of electron conduction. 